\title{
Myelin Proteolipid Protein Forms a Complex with Integrins and May Participate in Integrin Receptor Signaling in Oligodendrocytes
}

\author{
Tatyana I. Gudz, ${ }^{1}$ Tracy E. Schneider, ${ }^{1}$ Thomas A. Haas, ${ }^{2}$ and Wendy B. Macklin ${ }^{1}$ \\ Departments of ${ }^{1}$ Neurosciences and ${ }^{2}$ Molecular Cardiology, Lerner Research Institute, Cleveland Clinic Foundation, \\ Cleveland, Ohio 44195
}

\begin{abstract}
Myelination of axons in the CNS by oligodendrocytes is a process critical to rapid and efficient impulse conduction. A new role for the myelin proteolipid protein (PLP), the most abundant protein of CNS myelin, has been identified, in studies showing PLP interaction with signaling proteins in oligodendrocytes. In particular, these studies suggest that the PLP protein may be involved in signaling through integrins in oligodendrocytes. Stimulation of muscarinic acetylcholine receptors on oligodendrocytes induced formation of a tripartite complex containing PLP, calreticulin, and $\alpha_{\mathrm{v}}$-integrin. PLP interacted
\end{abstract}

The myelin proteolipid protein (PLP) and its alternatively spliced isoform DM20 are transmembrane proteins that constitute $\sim 50 \%$ of the protein in myelin (Eng et al., 1968; Lees and Brostoff, 1984). Despite the fact that PLP was identified more than 50 years ago (Folch and Lees, 1951) and it is an extremely abundant protein, no clear physiological role for this protein has been identified, although ionophoric activities have been proposed (Ting-Beall et al., 1979; Lin and Lees, 1982, 1984; Helynck et al., 1983; de Cozar et al., 1987; Diaz et al., 1990). In general, it has been assumed to function as a structural component of myelin, providing stability and maintaining the compact lamellar structure of myelin.

The current studies were initiated to investigate whether, in addition to its structural functions, PLP might be involved in signal transduction in oligodendrocytes. Thus, we investigated what proteins PLP interacts with and what consequences these interactions might have. PLP has four transmembrane domains with both N- and C-termini facing the cytosol (Popot et al., 1991; Weimbs and Stoffel, 1992; Gow et al., 1997). This tetraspan structure is distantly related to the tetraspanin family of proteins, which appears to be involved in signal transduction via interaction with integrin receptors (Maecker et al., 1997). A major function of integrins is to provide a physical connection between extracellular matrix (ECM) proteins and intracellular cytoskeletal-signaling molecules (Ruoslahti, 1996; Liu et al., 1999; Coppolino and Dedhar, 2000), including calreticulin (CRT), a multifunctional $\mathrm{Ca}^{2+}$-binding protein (Michalak et al., 1999). Integrins are

\footnotetext{
Received Jan. 28, 2002; revised June 14, 2002; accepted June 20, 2002.

This work was supported by National Institutes of Health Grant NS25304. We thank Dr. Tatiana Ugarova for helpful discussions, Natasha Podolnikova for help with binding assay, and Staci Raab for expert technical assistance. We thank Dr. Marjorie Lees for her initial work on this protein.

Correspondence should be addressed to Wendy B. Macklin, Department of Neurosciences NC30, Cleveland Clinic Foundation, 9500 Euclid Avenue, Cleveland, OH 44195. E-mail: mackliw@ccf.org.

Copyright (ㄷ) 2002 Society for Neuroscience $\quad 0270-6474 / 02 / 227398-10 \$ 15.00 / 0$
}

directly with the cytoplasmic domain of the $\alpha_{\mathrm{v}}$-integrin. Complex formation was mediated by phospholipase $\mathrm{C}$ and $\mathrm{Ca}^{2+}$ binding to the high affinity binding site on calreticulin. This complex appears important for binding of fibronectin to oligodendrocytes. These data establish a novel function for PLP as a part of the integrin signaling complex in oligodendrocytes and suggest that neurotransmitter-mediated integrin receptor signaling may be involved in myelinogenesis.

Key words: oligodendrocyte; myelin; proteolipid protein; integrin; calreticulin; muscarinic; acetylcholine receptor involved in signaling from the extracellular milieu into the cell, which is termed outside-in signaling, and their ligand binding activity can be modulated by intracellular signals, which is termed inside-out signaling. Inside-out signaling through integrins can originate from diverse plasma membrane receptors, including muscarinic acetylcholine receptors (mAChRs).

Both oligodendrocyte progenitors and myelinating oligodendrocytes are intimately associated with axons, suggesting the existence of neuronal signals affecting oligodendrocyte proliferation, migration, and differentiation (Levine, 1989; Notterpek and Rome, 1994; Barres and Raff, 1999). Although oligodendrocytes can differentiate without neurons, axons or axon-derived signals enhance myelin protein expression (Macklin et al., 1986; Kidd et al., 1990; Scherer et al., 1992). Axonal signals may also be required for oligodendrocyte survival (Barres and Raff, 1993), and it has been suggested that neuronal electrical activity is linked to myelinogenesis, perhaps by stimulating the release of growth factors and neurotransmitters from axons or from astrocytes or other glial cells (Barres and Raff, 1993; Demerens et al., 1996; Bergles et al., 2000). In addition, neurotransmitter receptors are expressed by oligodendrocytes at several stages of differentiation, which suggests that they might participate in oligodendrocyte differentiation (Belachew et al., 1999).

The current studies demonstrate that PLP may be involved in signaling through integrins and CRT, after $\mathrm{mAChR}$ activation in oligodendrocytes. Thus, agonist stimulation of the $\mathrm{mAChR}$ on oligodendrocytes is accompanied by a significant increase in a tripartite complex consisting of PLP, CRT, and $\alpha_{\mathrm{v}}$-integrin receptor, and this complex formation appears to modulate binding of ECM proteins to oligodendrocytes. Molecular details of these interactions and their consequences are presented. This is the first study to demonstrate an active role for PLP in signaling within the oligodendrocyte, and it suggests that PLP may be involved in neurotransmitter-induced adhesion events resulting from the neuron-oligodendroglial communication network. 


\section{MATERIALS AND METHODS}

Reagents and antibodies. U73343, U73122, $N$-ethylmaleimide (NEM), PMSF, leupeptin, aprotinin, carbamylcholine chloride (carbachol), atropine methyl bromide, and mouse monoclonal antibody to $2^{\prime}, 3^{\prime}$-cyclic nucleotide $3^{\prime}$-phosphodiesterase (CNP) were from Sigma (St. Louis, MO). Sulfosuccinimidobiotin [NHS-biotin], immobilized neutravidin, ditiobis [succinimidylpropionate] (DTSSP) were purchased from Pierce (Rockford, IL). H-Arg-Gly-Asp-Ser-OH (RGDS) was purchased from Calbiochem (La Jolla, CA).

Rabbit polyclonal antibodies to CRT were purchased from StressGen (Victoria, British Columbia, Canada). Human plasma fibronectin, rabbit polyclonal antibody to $\alpha_{\mathrm{v}}$-integrin, antibody to $\alpha_{1}$-integrin (clone FB12), antibody to $\alpha_{6}$-integrin (clone 4F10), polyclonal antibody to integrin $\beta 1$, polyclonal antibody to integrin $\beta 5$, and antibody to integrin $\beta 3$ (clone25E11) were purchased from Chemicon (Temecula, CA). Mouse monoclonal antibody to myelin basic protein (MBP) was obtained from Sternberger Inc. (Baltimore, MD). Rat monoclonal PLP antibody specific for the extracellular C-D loop of PLP was purchased from Immunodiagnostics, Inc. (Woburn, MA). Rat monoclonal PLP antibody (AA3) specific for the PLP/DM20 C terminus was a gift from Dr. Steven Pfeiffer (University of Connecticut, Storrs, CT). Monoclonal antibody to myelin oligodendrocyte glycoprotein (MOG) was a gift from Dr. Minnetta Gardinier (University of Iowa, Iowa City, IA). Affinity-purified rabbit polyclonal antibody to integrin $\beta 8$ was a generous gift from Dr. Stephen Nishimura (University of California at San Francisco, San Francisco, CA).

Primary cell cultures and lysate preparation. Primary cultures of mixed glial cells were prepared from rat pups as described (McCarthy and de Vellis, 1980) and modified (Duchala et al., 1995). Cells were plated on poly-D-lysine-coated plates and grown in DMEM with $10 \%$ fetal bovine serum (FBS) at $37^{\circ} \mathrm{C}$ and $5 \% \mathrm{CO}_{2}$ for $21 \mathrm{~d}$. Enriched oligodendrocyte cultures were prepared by shaking mixed glial cells at $10 \mathrm{~d}$ in vitro (DIV). Cells were shaken initially for $1 \mathrm{hr}$ at $100 \mathrm{rpm}$ to remove microglia, refed, and shaken $20-24 \mathrm{hr}$ at $37^{\circ} \mathrm{C}$ at $200 \mathrm{rpm}$. Enriched oligodendrocytes were plated on poly-D-lysine-coated plates and allowed to differentiate in $\mathrm{DMEM} / \mathrm{N} 2$ for $8 \mathrm{~d}$.

Cell lysates were made using lysis buffer: $0.15 \mathrm{M} \mathrm{NaCl}, 0.05$ м Tris, 0.5 mM EDTA, $1 \%$ Triton X-100, and $0.05 \%$ SDS, pH 7.5, supplemented with protease inhibitors cocktail $(20 \mu \mathrm{g} / \mathrm{ml}$ leupeptin, $100 \mu \mathrm{g} / \mathrm{ml}$ aprotinin, $2 \mathrm{~mm}$ PMSF, and $5 \mathrm{~mm}$ NEM). After $1 \mathrm{hr}$ on ice, samples were centrifuged at $15,000 \times g$ for 10 min to remove insoluble material. Supernatant protein concentrations were determined by bicinchoninic acid method (Sigma).

Myelin was prepared by the standard Norton and Poduslo (1973) protocol.

Immunofluorescence. Live mixed glial cultures (21 DIV) were washed twice with PBS and incubated with a mixture of primary antibodies, anti-CRT (1:25) and anti-PLP C-D loop (1:15) in DMEM, 5\% FBS for $25 \mathrm{~min}$ at room temperature. Cells were then stained with fluorescein anti-rat $\operatorname{IgG}$ (PLP) and biotinylated anti-rabbit $\operatorname{IgG}$ for $25 \mathrm{~min}$. Cells were washed and incubated with cy5 Streptavidin (1:500) for additional 25 min to complete staining for CRT. Cells were briefly fixed with $4 \%$ paraformaldehyde, and coverslips were mounted with Vectashield. Images were collected at $63 \times$ magnification on a Leica TCS NT confocal system. CRT images are presented here in red.

Western blotting and immunoprecipitation. For immunoprecipitation reactions, lysates $(1 \mathrm{mg} / \mathrm{ml})$ were precleared in immunoprecipitation (IP) buffer: $0.15 \mathrm{M} \mathrm{NaCl}, 0.05 \mathrm{~m}$ Tris, $0.5 \mathrm{~mm}$ EDTA, $1 \%$ Triton X-100, $0.05 \%$ SDS, and $2 \%$ bovine serum albumin (BSA), $\mathrm{pH} 7.5$, supplemented with protease inhibitors $(20 \mu \mathrm{g} / \mathrm{ml}$ leupeptin, $100 \mu \mathrm{g} / \mathrm{ml}$ aprotinin, $2 \mathrm{~mm}$ PMSF, and $5 \mathrm{~mm} \mathrm{NEM)} \mathrm{by} \mathrm{incubation} \mathrm{with} \mathrm{appropriate} \mathrm{species-specific}$ IgG-conjugated magnetic beads (Dynabeads; Dynal, Lake Success, NY). Antibody was then added. After incubation at $4^{\circ} \mathrm{C}$ ON with gentle mixing, antibody-antigen complexes were captured with Dynabeads and washed. Immunoprecipitates were eluted by boiling in SDS sample buffer in the absence ( $\alpha_{\mathrm{v}}$-integrin and $\beta$-integrins blots) or presence (all other proteins) of reducing agent. Lysates and immunoprecipitates were separated on $8.5-10 \%$ SDS PAGE, blotted to the polyvinylidene difluoride membrane, blocked with $5 \%$ nonfat dry milk in TBS-T buffer $(10 \mathrm{~mm}$ Tris, $150 \mathrm{~mm} \mathrm{NaCl}$, and $0.2 \%$ Tween $20, \mathrm{pH} 8.0$ ) $\mathrm{ON}$ at $4^{\circ} \mathrm{C}$, and subsequently probed with appropriate antibody according to Kuryshev et al. (2000). Immunoreactive bands were visualized using enhanced chemiluminescence kit (ECL-Plus; Amersham Pharmacia Biotech, Piscataway, NJ).

Biotinylation and cross-linking. To biotinylate cell surface proteins, cells were washed three times with PBS, $\mathrm{pH} 8.0$, and incubated with $1 \mathrm{~mm}$
NHS-SS-biotin in PBS for $30 \mathrm{~min}$ at room temperature. Unreacted biotin was removed by washing three times with ice-cold PBS. Cell lysates were immunoprecipitated with anti-PLP antibody (1:50). Antigen-antibody complexes were captured with Dynabeads. Immunocomplexes were eluted from the Dynabeads by incubating with $10 \mathrm{~mm}$ DTT in PBS for $3.5 \mathrm{hr}$ at $37^{\circ} \mathrm{C}$. To separate biotinylated proteins, $0.75 \mathrm{ml}$ of the sample was applied to $0.3 \mathrm{ml}$ of $50 \%$ slurry of neutravidin beads, which had been washed with PBS. The mixture was incubated at $4^{\circ} \mathrm{C}$ ON with rotation. Biotinylated proteins were eluted by boiling Dynabeads in SDS sample buffer.

To cross-link cell surface proteins, cells were incubated for $30 \mathrm{~min}$ at $22^{\circ} \mathrm{C}$ in PBS, $\mathrm{pH} 8.0$, containing $0.5 \mathrm{~mm}$ DTSSP. Cross-linking reaction was stopped with $50 \mathrm{~mm}$ Tris/ $\mathrm{HCl}, \mathrm{pH}$ 7.4. Cells were washed three times with PBS and solubilized in lysis buffer supplemented with protease inhibitors. Samples were analyzed by immunoprecipitation and Western blot. Samples were analyzed on reducing and nonreducing gels. On nonreducing gels, cross-linked proteins will comigrate. However, the DTSSP disulfide bond is cleaved by reducing agent, and the cross-linked proteins migrate at their native size on the gel in reducing gels.

Peptide synthesis, purification, and immobilization. Peptides were synthesized as described (Vinogradova et al., 2000). Briefly, peptides were synthesized on 4-methylbenzhydrylamine resins ( $\alpha$-carboxamides) or on appropriate Boc-aminoacyl-OCH${ }_{2}-\mathrm{Pam}$ resins (carboxylates). The synthesis followed a manual stepwise in situ neutralization-activation protocol using tert-butyloxycarbonyl (Boc) protection, monitoring coupling efficiency by quantitative ninhydrin method. Myristoylation of the $\mathrm{N}$ terminus of peptides was performed with myristic acid and 1,3diisopropylcarbodiimide $(1: 0.95 \mathrm{~mol}: \mathrm{mol})$ in a mixture of dichloromethane:dimethylformamide $(4: 1, \mathrm{vol} / \mathrm{vol})$, following standard solution methods. Synthetic peptides were cleaved from the resin and deprotected by hydrofluoric acid, extracted into aqueous acetic acid, then purified by C18 reverse-phase HPLC. The purity of each peptide was confirmed to be $>98 \%$, as assessed by analytical HPLC and mass-spectroscopy.

To prepare immobilized peptide, cysteine was added to the $\mathrm{N}$ terminus of non-myristoylated peptides, and then peptides $(10 \mathrm{mg})$ were dissolved in $50 \mathrm{~mm}$ Tris, $5 \mathrm{~mm}$ EDTA, $\mathrm{pH} 8.5$, and coupled to resin by incubating ON with $2 \mathrm{ml}$ of SulfoLink resin (Pierce, Rockford IL). Percentage of coupling was $>99 \%$, as assessed by using Ellman's reagent. Cysteine alone was used for the control column. Equal amounts of cell lysate were passed through each column twice, then the columns were extensively washed with PBS to remove all unbound material. The proteins bound to the column were eluted with a buffer containing $0.5 \mathrm{M} \mathrm{NaCl}, 0.1 \mathrm{M}$ glycine, $\mathrm{pH} 3.0,0.05 \%$ Triton X-100, and $0.01 \%$ SDS and analyzed by Western blotting.

Fibronectin binding assay. Fibronectin or BSA was labeled with Alexa Fluor 488 fluorescent dye using a protein labeling kit (Molecular Probes, Eugene, OR) according to the manufacturer's instructions. A fibronectin binding assay was performed, as described in Vinogradova et al. (2000). Briefly, enriched oligodendrocytes, grown in 96-well microtiter plates (Corning Costar Corp., Cambridge, MA), were incubated with $50 \mu \mathrm{M}$ RGDS peptide or antibodies $(1: 100)$ for $30 \mathrm{~min}$ at $37^{\circ} \mathrm{C}$ and $5 \% \mathrm{CO}_{2}$, stimulated with $2 \mathrm{mM} \mathrm{Ca}^{2+}$ and/or $100 \mu \mathrm{M}$ carbachol for $10 \mathrm{~min}$. Then, $10 \mu \mathrm{g} /$ well fibronectin-Alexa Fluor 488 conjugate was added, and the incubation continued for $30 \mathrm{~min}$. Control experiments using BSA-Alexa Fluor 488 conjugate were done identically. Cells were washed twice with PBS. Fluorescence in each well was measured at $530 \mathrm{~nm}$ with $480 \mathrm{~nm}$ excitation using a CytoFluor Multiwell Plate Reader (PerSeptive Biosystems). Replicates of three to six wells of cells were used in each experiment, and multiple experiments were averaged. Data from the binding assays are expressed as mean \pm SEM. Differences were compared by one-way ANOVA and Student-Newman-Keuls post hoc test. Means were considered to be significantly different when $p<0.05$.

\section{RESULTS}

\section{PLP exists in a complex with the $\alpha_{\mathrm{v}}$ integrin receptor}

Integrins exist as heterodimers of $\alpha$ and $\beta$ subunits, which are transmembrane glycoproteins. To investigate whether PLP exists in a complex with integrin receptors, we conducted coimmunoprecipitation experiments from differentiated oligodendrocytes in mixed glial culture using antibodies to various integrin receptor $\alpha$-subunits. Western blots were probed with antibody directed against the $\mathrm{C}$ terminus of PLP, which can recognize both PLP and DM20. In oligodendrocytes, PLP coimmunoprecipitated with 


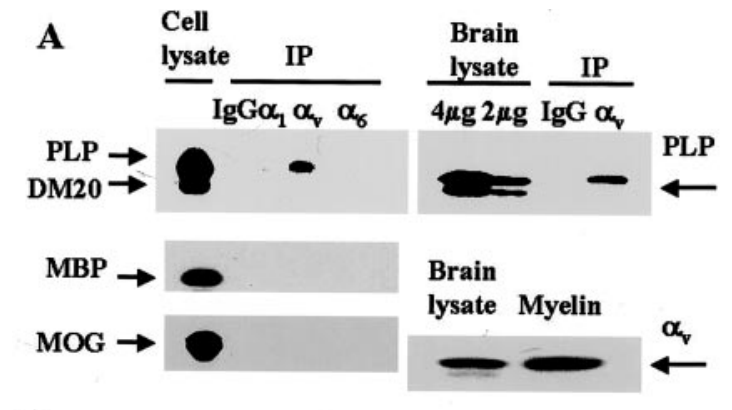

B

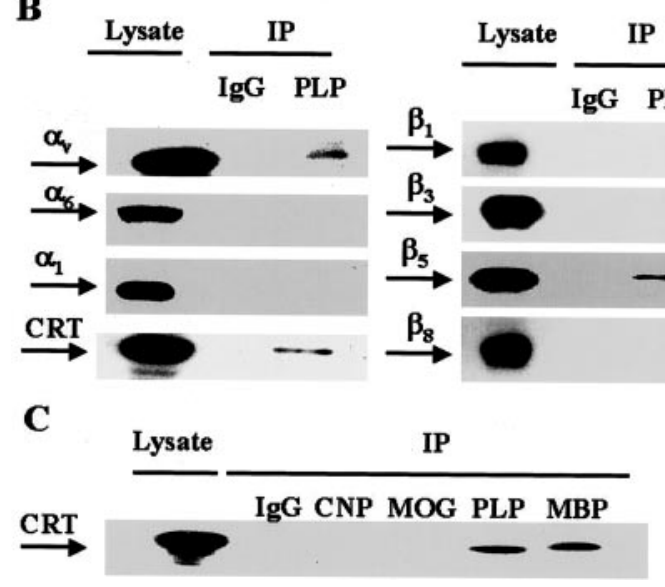

Figure 1. PLP exists in a complex with CRT and $\alpha_{\mathrm{v}}$-integrin receptor. $A$, PLP specifically interacts with $\alpha_{\mathrm{v}}$-integrin in oligodendrocytes in mixed glial cultures (left panel) and in brain (top right panel). Cell lysates were immunoprecipitated with control IgG (1:100), $\alpha_{1}$-integrin antibody (1: $100), \alpha_{\mathrm{v}}$-integrin antibody (1:100), or $\alpha_{6}$-integrin antibody (1:100). Immunoprecipitates and cell lysate $(8 \mu \mathrm{g})$ or brain lysate $(2$ or $4 \mu \mathrm{g})$ were loaded onto SDS-polyacrylamide gel and analyzed by Western blots using PLP antibody, which recognizes both PLP and DM20 (1:100), MBP antibody (1:500), or MOG antibody (1: 200). Whole rat brain lysate $(5 \mu \mathrm{g})$ and purified myelin $(5 \mu \mathrm{g})$ samples were analyzed by SDS-PAGE and Western blotting using polyclonal $\alpha_{\mathrm{y}}$-integrin antibody (1:100) (bottom right panel). $B$, Coimmunoprecipitation of $\alpha_{\mathrm{v}} \beta 5$ integrin with PLP and CRT from oligodendrocytes in mixed glial cultures. Cell lysates were immunoprecipitated with PLP antibody (1:50), and then analyzed by Western blots along with aliquots of lysate $(5 \mu \mathrm{g})$ using $\alpha_{\mathrm{v}}$ antibody (1:100), $\alpha_{6}$ antibody (1:200), $\alpha_{1}$ antibody (1:100), $\beta 1$ antibody (1:100), $\beta 3$ antibody (1:200), $\beta 5$ antibody (1:100), $\beta 8$ antibody (1:200), or CRT antibody (1:100). C, Coimmunoprecipitation of CRT with PLP or MBP from oligodendrocytes in mixed glial cultures. Cell lysates were immunoprecipitated with MOG, CNP, PLP, or MBP antibody (1:50) and analyzed on Western blots with CRT antibody (1:100). Lysate samples were $3 \mu \mathrm{g}$.

$\alpha_{\mathrm{v}}$ - integrin (Fig. 1A) but did not coimmunoprecipitate with control IgG or $\alpha_{6}$-integrin, which is another $\alpha$-integrin expressed by oligodendrocytes. Additionally, it did not coimmunoprecipitate with $\alpha_{1}$-integrin, which is not expressed in oligodendrocytes, but rather in astrocytes (Tawil et al., 1994), which are abundant in the mixed glial cultures. These data demonstrated that PLP interaction with integrin was specific for the $\alpha_{\mathrm{v}}$-integrin present in oligodendrocytes. There was no $\alpha_{\mathrm{v}}$-integrin association with MBP or MOG, which are other myelin proteins expressed by differentiated oligodendrocytes (Fig. 1A). To confirm that this interaction was not a culture artifact, we analyzed brain homogenates; PLP also coimmunoprecipitated with $\alpha_{\mathrm{v}}$ - integrin receptor from brain (Fig. 1A). In contrast, DM20 was not detected in immunoprecipitates from either cultured oligodendrocytes or brain. To assess whether the localization of $\alpha_{\mathrm{v}}$-integrin in brain brought it into proximity of PLP, we analyzed its expression in compact myelin, where PLP is localized. The $\alpha_{\mathrm{v}}$-integrin was found in compact myelin (Fig. $1 A$ ), where it was, in fact, enriched relative to whole brain lysate.

To confirm the PLP association with $\alpha_{\mathrm{v}}$-integrin, the reciprocal coimmunoprecipitation experiments were performed. PLP antibody immunoprecipitated $\alpha_{\mathrm{v}}$-integrin from the oligodendrocyte lysate (Fig. $1 B$ ) and from whole brain lysate (data not shown). To determine which integrin receptor is associated with PLP, the immunoprecipitates were tested with antibodies directed against the $\alpha$-subunits $\left(\alpha_{1}\right.$ and $\left.\alpha_{6}\right)$ present in mixed glial cultures and $\beta$-subunits $(\beta 1, \beta 3, \beta 5$, and $\beta 8)$ expressed in oligodendrocytes (Milner and ffrench-Constant, 1994). PLP coimmunoprecipitated specifically with $\alpha_{\mathrm{v}} \beta 5$ integrin (Fig. 1B), but not other $\beta$-integrins. The association of CRT with PLP was also studied, because it is known to bind to the cytoplasmic domain of the $\alpha_{\mathrm{v}}$-integrin (Rojiani et al., 1991); there was a clear association of PLP with CRT (Fig. 1B). Thus, in oligodendrocytes, PLP associated with both CRT and $\alpha_{\mathrm{v}} \beta 5$ integrin receptor. Neither CNP nor MOG-specific antibody precipitated CRT, and although MBP antibody immunoprecipitated CRT (Fig. 1C), it was not detected in the immunoprecipitate with the $\alpha_{\mathrm{v}}$-integrin and PLP (Fig. 1A). Thus, although there may be an association of MBP with CRT in oligodendrocytes, it is not part of the complex with $\alpha_{\mathrm{v}}$-integrin, CRT and PLP. Taken together, these data suggest that PLP can form a unique tripartite complex with CRT and $\alpha_{\mathrm{v}} \beta 5$ integrin in differentiated oligodendrocytes.

\section{CRT exists in a complex with PLP at the cell surface}

Both PLP and $\alpha_{\mathrm{v}} \beta 5$ integrin are integral membrane proteins localized at the plasma membrane, suggesting that the complex of PLP, $\alpha_{\mathrm{v}} \beta 5$ integrin and CRT may exist at the surface of oligodendrocyte. However, CRT has well recognized physiological roles in the endoplasmic reticulum (ER) as a molecular chaperone and $\mathrm{Ca}^{2+}$-signaling molecule (Michalak et al., 1999). On the other hand, recent data suggest that despite the presence of a KDEL sequence, i.e., an ER retention signal, CRT can also be found at the surface of cells, such as in the neuronal cell line NG-108-15 (Johnson et al., 2001). To examine whether CRT was localized at the plasma membrane in oligodendrocytes, cell surface proteins were cross-linked using the membrane-impermeable cross-linking reagent (DTSSP), and subsequently immunoprecipitated with PLP antibody (Fig. $2 A, B$ ). Because DTSSP is a cleavable cross-linking reagent, the cross-linking disulfide bond is cleaved by reducing agent in the sample buffer, and the crosslinked proteins migrate at their native size on the gel. The amount of CRT in the PLP immunoprecipitate (reducing gel) increased after cross-linking, suggesting that CRT may be at the surface of the oligodendrocyte in close proximity to PLP, and that after cross-linking, more is associated with PLP (Fig. 2A). There was no MBP detected in the immunoprecipitates. Because $\mathrm{MBP}$ is also at the plasma membrane, but on the cytoplasmic surface, this is consistent with the cell surface impermeance of DTSSP, and the specificity of the PLP-CRT interaction at the cell surface. The PLP immunoprecipitate was also analyzed on nonreducing gel (Fig. 2B). As expected, both CRT and PLP co-migrated as a higher molecular weight protein complex after cross-linking. As another approach to confirm the cell surface localization of this interaction, surface proteins were biotinylated, and biotinylated proteins from a PLP immunoprecipitate were purified using neutravidin beads (Fig. 2C). PLP antibody precipitated biotinylated CRT, supporting the concept that CRT could 


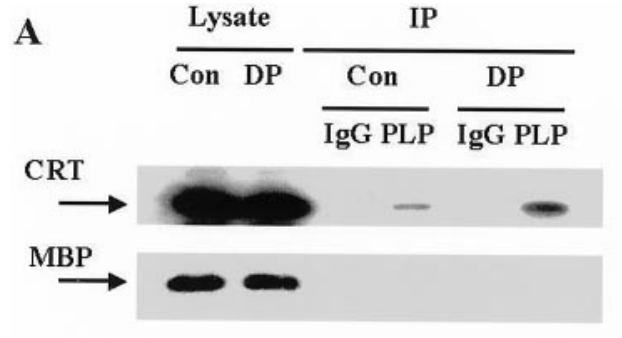

$\mathbf{B}$

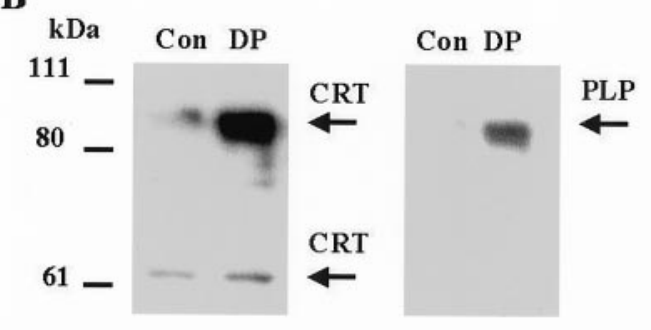

C

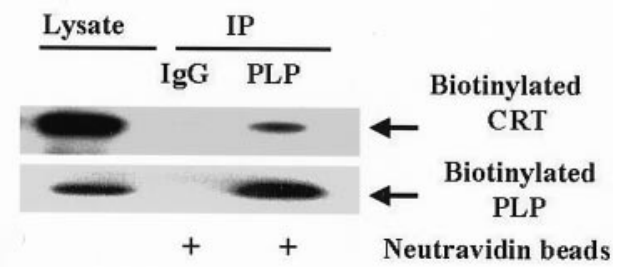

Figure 2. CRT forms a complex with PLP at the cell surface. A, Cell surface proteins were cross-linked with DTSSP, as described in Materials and Methods. Cell lysates were immunoprecipitated with control IgG (1:100) or PLP antibody (1:50). Control cell lysates (Con, $3 \mu \mathrm{g})$, DTSSPcross-linked cell lysates $(D P, 3 \mu \mathrm{g})$, and immunoprecipitates from equal amounts of the lysate were loaded onto SDS-polyacrylamide gel containing reducing agent, and then analyzed by Western blots using CRT antibody (1:100) or MBP antibody (1:500). $B$, The PLP immunoprecipitates from control cells and after cross-linking with DTSSP were eluted in nonreducing sample buffer and loaded onto nonreducing SDSpolyacrylamide gels. Samples were analyzed by Western blotting first with CRT antibody (1:100, left panel), then the blot was stripped and re-probed with PLP antibody (1:100, right panel). Note co-migrating band. $C$, Biotinylation of cell surface proteins was performed on mixed glial cultures, as described in Materials and Methods. Cell lysate $(3 \mu \mathrm{g})$ and equal amounts of immunoprecipitated protein samples bound to neutravidin beads were loaded onto the gel and analyzed by Western blots using PLP antibody $(1: 100)$ and CRT antibody $(1: 100)$.

form a complex with PLP and $\alpha_{\mathrm{v}} \beta 5$ integrin receptor at the oligodendrocyte plasma membrane.

Further confirmation of the surface expression of CRT in oligodendrocytes was obtained by staining live cells. Thus, mixed glial cells were incubated with antibodies against CRT and PLP. Incubation with antibody against the C terminus of PLP did not stain live cells, although it did stain fixed cells (data not shown). On the other hand, oligodendrocytes in the mixed cultures stained with antibody for a surface epitope of PLP, the C-D loop, and with antibody against CRT (Fig. 3). Clearly both PLP and CRT were detectable at the surface of oligodendrocytes, and there appeared to be some colocalization of signal.

\section{Stimulation of mAChR triggers formation of a tripartite complex}

It has been shown that integrins represent downstream effectors of mAChRs and that integrin activation in response to $\mathrm{mAChR}$ stimulation results in focal adhesion formation in human embry-

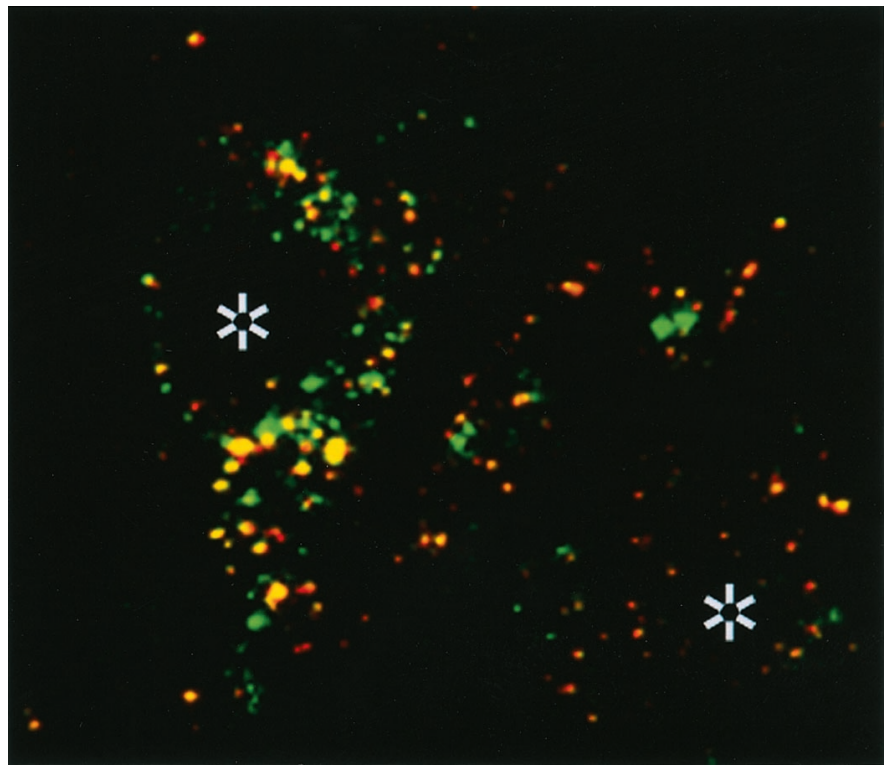

Figure 3. CRT and PLP associate at the surface of oligodendrocytes. Live mixed glial cultures (21 DIV) were incubated with antibodies against the $\mathrm{C}$ terminus of CRT (red image) and a surface epitope of the PLP protein (FITC). Asterisks denote two cell bodies.

onic kidney (HEK) cells (Slack, 1998). Because oligodendrocytes express m1, m2, and m3 mAChRs (Cohen and Almazan, 1994; Simpson and Russel, 1996), we tested the physiological significance of the PLP association with the integrin receptor and CRT by studying formation of the tripartite complex after agonist stimulation of mAChR. Analysis of the carbachol effect on the formation of the PLP/CRT $/ \alpha_{\mathrm{v}}$ integrin complex revealed a timedependent increase in the CRT and $\alpha_{\mathrm{v}}$-integrin association with PLP (Fig. 4A). Comparable results were obtained for oligodendrocytes shaken and purified from mixed glial cultures, indicating that the mAChRs on the oligodendrocytes themselves were responsible for the response, not those on astrocytes in the mixed glia (Fig. $4 B$ ). The increase in binding of both CRT and $\alpha_{\mathrm{v}}$ integrin was maximal after 10 min treatment with carbachol and declined somewhat by $20 \mathrm{~min}$. Preincubation of the cells with 20 $\mu \mathrm{M}$ atropine, a potent $\mathrm{mAChR}$ antagonist, reduced the carbacholinduced response at $10 \mathrm{~min}$. To further test the specificity of the PLP and $\alpha_{\mathrm{v}} \beta 5$ interaction, the PLP immunoprecipitates from carbachol-treated mixed glial cultures were analyzed for the presence of the other $\alpha$-subunits and $\beta$-subunits present in these cultures. PLP did not interact with $\alpha_{1}, \alpha_{6}, \beta 1, \beta 3$, or $\beta 8$ in cells treated with carbachol for $10 \mathrm{~min}$ (data not shown).

Two forms of $\alpha_{\mathrm{v}}$-integrin precipitated with PLP: a band migrating at $165 \mathrm{kDa}$ protein and another band migrating at 150 $\mathrm{kDa}$ protein, which corresponded to the predominant form of the $\alpha_{\mathrm{v}}$-integrin in the lysate. It has been established that many $\alpha$-integrin precursors, including $\alpha_{\mathrm{v}}$-integrin, undergo a posttranslational endoproteolytic cleavage in the membrane-proximal extracellular region (Delwel et al., 1996). Thus, the $165 \mathrm{kDa}$ protein is likely the $\alpha_{\mathrm{v}}$-integrin precursor, whereas the $150 \mathrm{kDa}$ band represents the cleaved $\alpha_{\mathrm{v}}$-integrin. PLP association with the putative uncleaved $\alpha_{\mathrm{v}}$-integrin precursor was somewhat increased by carbachol treatment, but more strikingly, there was a dramatic time-dependent increase in PLP association with the classical $\alpha_{\mathrm{v}}$-integrin after carbachol stimulation of $\mathrm{mAChR}$, and this was prevented by atropine. 


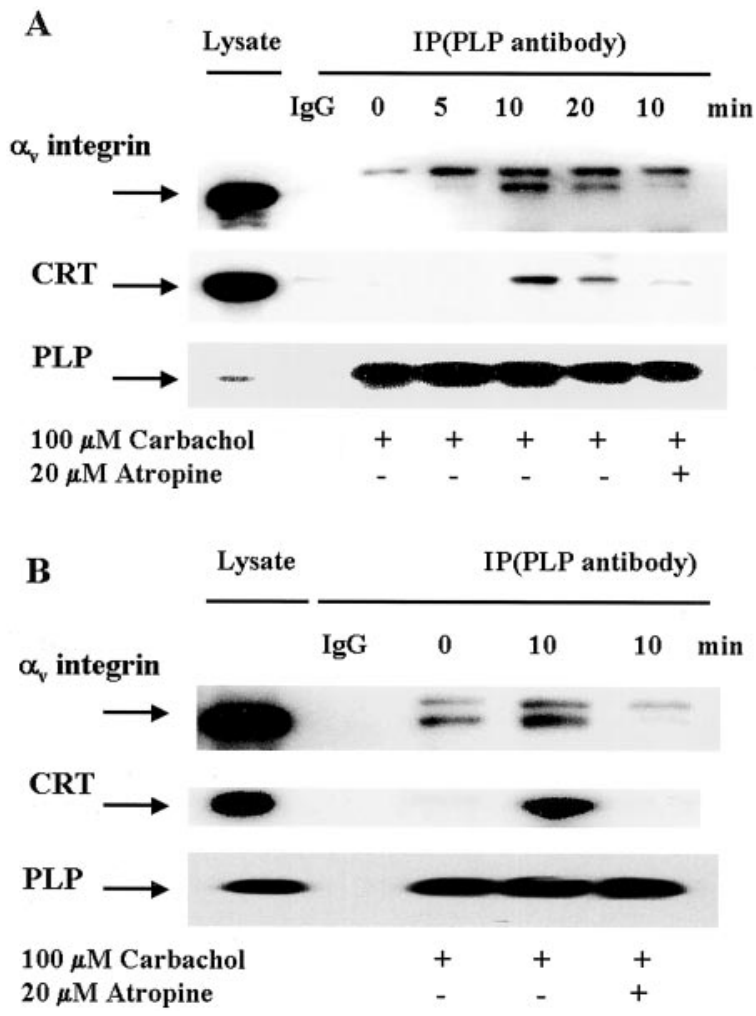

Figure 4. Carbachol stimulates formation of a tripartite complex in cultured oligodendrocytes. Mixed glial cultures $(A)$ or enriched oligodendrocytes $(B)$ were stimulated with carbachol. Cell lysates were immunoprecipitated with control IgG (1:100) or PLP antibody (1:50) and analyzed by Western blotting using $\alpha_{\mathrm{v}}$ antibody (1:100), CRT antibody (1:100), or PLP antibody (1:100). Lysate samples contained $5 \mu \mathrm{g}$ of protein $\left(\alpha_{v}\right.$-integrin $)$ or $3 \mu \mathrm{g}$ of protein $(C R T, P L P)$. One sample was incubated with carbachol for $10 \mathrm{~min}$ after $30 \mathrm{~min}$ pretreatment with atropine.

\section{Direct interaction of PLP with $\alpha_{\mathrm{v}}$-integrin}

We next focused on defining the interactions of the proteins within the PLP/CRT $/ \alpha_{\mathrm{v}}$ complex. The integrin receptor could interact directly with PLP or with CRT, which could, in turn, recruit PLP to the complex. To determine whether PLP interacted directly with the integrin receptor, we analyzed cells that were stimulated with carbachol in the presence of synthetic peptides mimicking the inactive and active forms of the cytosolic domain of the $\alpha_{\mathrm{v}}$-integrin receptor. TH110 is the full length C-terminal cytoplasmic domain of the $\alpha_{\mathrm{v}}$-integrin, and TH126 is the $\mathrm{C}$ terminus minus the terminal 10 amino acids (Fig. $5 A$ ). The $\mathrm{N}$ terminus of the peptides is modified by myristoylation, which allows peptides to traverse the plasma membrane into cells and acts as a surrogate transmembrane domain that anchors proteins and domains onto the membrane surface, similar to the cytoplasmic domains of intact receptors (Vinogradova et al., 2000). The current conformation-based model for integrin activation, as determined by nuclear magnetic resonance (Vinogradova et al., 2000), suggests that the full-length nonactivated cytoplasmic tail of $\alpha_{\mathrm{v}}$-integrin is in a "closed" conformation, whereas the $\mathrm{N}$-terminal membrane-proximal region forms an $\alpha$-helix followed by a turn. The structure of the shorter, activated $\alpha_{\mathrm{v}}$ cytoplasmic domain is significantly different, having an "open" conformation. Thus, full-length TH110 is likely to be in a closed nonactivated conformation, unable to compete with the activated native full-

\section{A $\quad$ TH110 \\ XRMGFFKRVRPPQEEQEREQLQPHENGEGN TH126}

XRMGFFKRVRPPQEEQEREQ

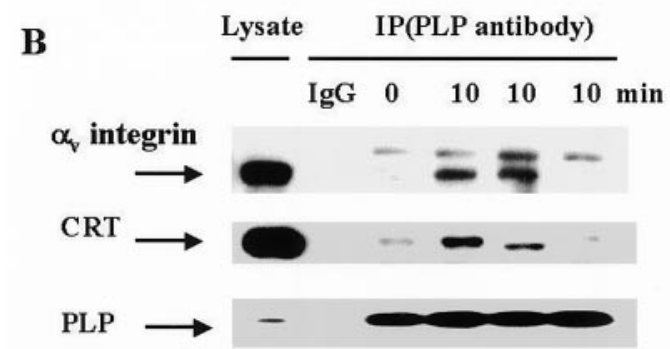

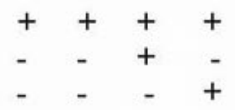

C

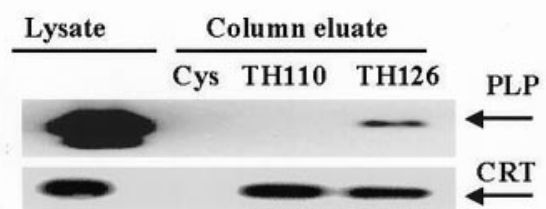

Figure 5. Direct interaction of PLP and $\alpha_{\mathrm{v}}$-integrin in oligodendrocytes in mixed glial cultures. $A$, Amino acid sequence of the myristoylated peptide TH110, the cytosolic C terminus of $\alpha_{\mathrm{v}}$-integrin, and the truncated myristoylated C-terminal peptide TH126. B, Coimmunoprecipitation of $\alpha_{\mathrm{v}}$-subunit, CRT, and PLP. Cells were preincubated with or without 50 $\mu \mathrm{M}$ peptide in serum-free medium for $1 \mathrm{hr}$. Cells were then exposed to carbachol for $10 \mathrm{~min}$, and lysates were prepared. Cell lysates were immunoprecipitated with control $\operatorname{IgG}(1: 100)$ or PLP antibody (1:50) and analyzed by Western blotting using $\alpha_{\mathrm{v}}$-integrin antibody (1:100), CRT antibody (1:100), or PLP antibody (1:100). Lysate samples contained $5 \mu \mathrm{g}$ of protein $\left(\alpha_{v}\right.$-integrin $)$ or $3 \mu \mathrm{g}$ of protein $(C R T, P L P)$. C, PLP and CRT binding to immobilized peptides. Cell lysate was passed through a control cysteine-linked column (Cys), a TH110 peptide-linked column, or a TH126 peptide-linked column. The columns were washed with PBS and eluted. Eluted proteins were analyzed by Western blotting using PLP antibody (1:100) or CRT antibody (1:100). Lysate samples contained $3 \mu \mathrm{g}$ of protein.

length cytoplasmic domain of the $\alpha_{\mathrm{v}}$ cytoplasmic tail in open conformation. In contrast, the shorter peptide, TH126, should act as a competitive inhibitor.

We tested whether these peptides could serve as competitive inhibitors of the PLP interaction with the integrin receptor. Treatment of oligodendrocytes with full-length peptide TH110 had no effect on the interaction of PLP with $\alpha_{\mathrm{v}}$-integrin or with CRT, after carbachol treatment (Fig. 5B). By contrast, the truncated peptide (TH126) caused a significant depletion of the $\alpha_{\mathrm{v}}$-integrin in the PLP immunoprecipitate. Thus, it blocked the interaction of these two proteins, suggesting that PLP interacts directly with the cytoplasmic domain of the $\alpha_{\mathrm{v}}$-integrin. In the presence of TH126, CRT was also no longer associated with PLP. Thus, preventing PLP interaction with activated $\alpha_{\mathrm{v}}$-integrin blocked the interaction of PLP and CRT, suggesting that CRT is associated with PLP by binding to $\alpha_{\mathrm{v}}$-integrin, which in turn binds to PLP, after mAChR stimulation of oligodendrocytes.

These studies strongly suggested that binding is directly between PLP and the cytoplasmic domain of activated $\alpha_{\mathrm{v}}$-integrin. We tested this further by studying whether PLP would bind to immobilized TH110 or TH126 (Fig. 5C). Whereas CRT bound to 


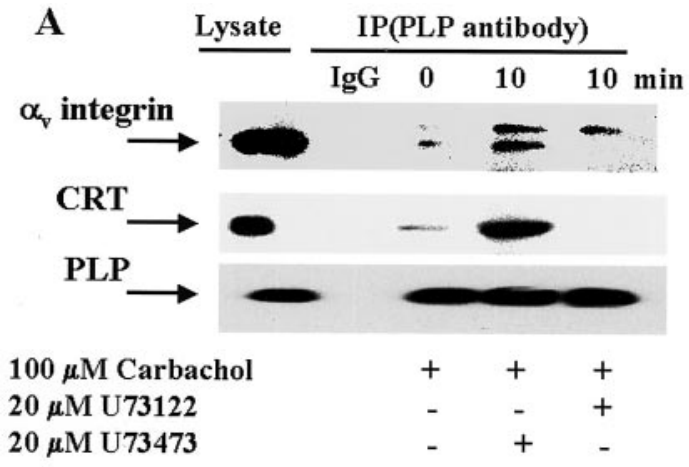

B

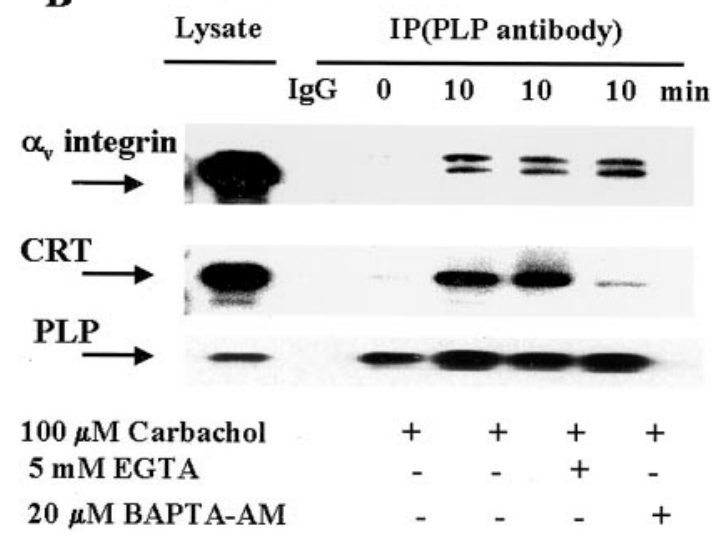

Figure 6. The tripartite complex formation is mediated by PLC and intracellular $\mathrm{Ca}^{2+} . A$, Cells were preincubated with or without the PLC inhibitor (U73122) or its inactive analog (U73473) for $30 \mathrm{~min}$, and were then stimulated with carbachol for $10 \mathrm{~min}$. Cell lysates were immunoprecipitated with control IgG (1:100) or PLP antibody (1:50), and analyzed by Western blotting using CRT, $\alpha_{\mathrm{v}}$-integrin, or PLP antibody (1:100). Lysate samples contained $5 \mu \mathrm{g}$ of protein $\left(\alpha_{v}\right.$-integrin $)$ or $3 \mu \mathrm{g}$ of protein $(C R T, P L P)$. B, Cells were preincubated with BAPTA-AM for $30 \mathrm{~min}$ or with EGTA for $10 \mathrm{~min}$ and stimulated with carbachol for $10 \mathrm{~min}$. Cell lysates were immunoprecipitated with control IgG (1:100) or PLP antibody and analyzed by Western blotting using CRT, $\alpha_{\mathrm{v}}$-integrin, or PLP antibody (1:100). Lysate samples contained $5 \mu \mathrm{g}$ of protein $\left(\alpha_{v}\right.$-integrin) or $3 \mu \mathrm{g}$ of protein (CRT, PLP).

both TH110 and TH126, PLP selectively bound to TH126. Thus, only TH126 bound PLP in lysates and it competed for $\alpha_{\mathrm{v}}$-integrin association with PLP in oligodendrocytes. In conjunction with studies described below, which show that PLP can bind $\alpha_{\mathrm{v}^{-}}$ integrin in the absence of CRT, we conclude that PLP interacts directly with the C-terminal cytoplasmic domain of $\alpha_{\mathrm{v}}$-integrin in oligodendrocytes.

\section{Carbachol-induced PLP association with $\alpha_{\mathrm{v}}$-integrin depends on PLC and intracellular $\mathbf{C a}^{2+}$}

The $\mathrm{m} 1$ and $\mathrm{m} 3 \mathrm{mAChRs}$ expressed by oligodendrocytes are functionally linked to PLC activation (Cohen and Almazan, 1994). To determine whether the carbachol-induced formation of the tripartite complex was mediated by PLC, cells were pretreated with U73122 (a potent blocker of PLC) and then with carbachol. U73122 $(20 \mu \mathrm{M})$ completely abolished the PLP association with $\alpha_{\mathrm{v}}$-integrin and CRT (Fig. $6 \mathrm{~A}$ ). The inactive structural analog of this PLC inhibitor, U-73433 $(20 \mu \mathrm{M})$, did not affect complex formation. Thus, stimulation of mAChR triggered tripartite complex formation via activation of PLC in oligodendrocytes.

Activated PLC generates inositol 1,4,5-triphosphate $\left(\mathrm{IP}_{3}\right)$,

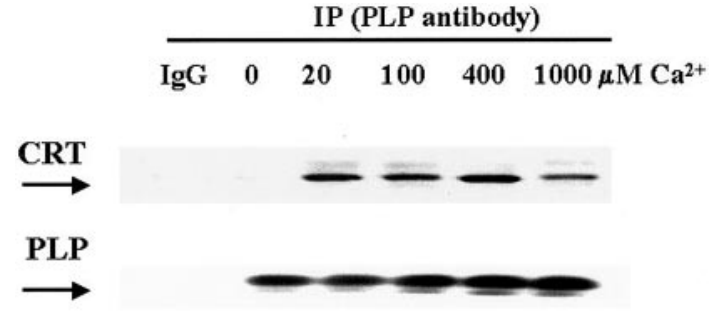

Figure 7. $\mathrm{Ca}^{2+}$ plays a role in $\mathrm{CRT}$ association with the complex. Cell lysates were prepared in the presence of various $\mathrm{Ca}^{2+}$ concentrations (1-1000 $\mu \mathrm{M})$, immunoprecipitated with PLP antibody (1:50) in the presence of the same $\mathrm{Ca}^{2+}$ concentrations that were used for the lysate, and analyzed by Western blotting using CRT or PLP antibody (1:100).

which releases $\mathrm{Ca}^{2+}$ from internal stores. In addition, carbachol stimulates extracellular $\mathrm{Ca}^{2+}$ influx in fibroblasts by opening plasma membrane channels (Felder et al., 1992). To determine whether $\mathrm{Ca}^{2+}$ is required for carbachol-induced formation of the complex between PLP, CRT, and $\alpha_{\mathrm{v}}$-integrin, intracellular or extracellular $\mathrm{Ca}^{2+}$ were depleted. Cells were loaded with $20 \mu \mathrm{M}$ BAPTA-AM (a cell-permeable $\mathrm{Ca}^{2+}$ chelator) for $30 \mathrm{~min}$, and then exposed to carbachol and analyzed for complex formation. The PLP- $\alpha_{\mathrm{v}}$-integrin receptor interaction was unchanged, relative to control (Fig. $6 B$ ), indicating that the PLP association with $\alpha_{\mathrm{v}}$-integrin is independent of intracellular $\mathrm{Ca}^{2+}$. By contrast, there was a significant decrease in CRT associated with the complex. Because chelation of intracellular $\mathrm{Ca}^{2+}$ blocked the carbachol-induced CRT association with the integrin receptor and PLP, it appears that the events triggered by $\mathrm{mAChR}$ stimulation depend on release of $\mathrm{Ca}^{2+}$ from intracellular stores, but only with respect to the association of CRT with the complex. The carbachol-induced PLP interaction with $\alpha_{\mathrm{v}}$-integrin appears to be independent of intracellular $\mathrm{Ca}^{2+}$. To assess whether extracellular $\mathrm{Ca}^{2+}$ was involved in carbachol-stimulated complex formation, cultures were preincubated with $5 \mathrm{~mm}$ EGTA to chelate extracellular $\mathrm{Ca}^{2+}$, and then treated with carbachol. Complex formation was unaffected by chelation of extracellular $\mathrm{Ca}^{2+}$ (Fig. $6 B)$, which implies that influx of extracellular $\mathrm{Ca}^{2+}$ is not necessary for carbachol-induced CRT or PLP interaction with $\alpha_{\mathrm{v}}$ integrin receptor.

Because changes in intracellular $\mathrm{Ca}^{2+}$ concentration impacted the association of CRT with the complex, we tested the amount of intracellular $\mathrm{Ca}^{2+}$ that was important. CRT association with the integrin receptor can be modulated by $\mathrm{Ca}^{2+}$ binding to either of two sites on CRT, a low-affinity $\left(K_{\mathrm{d}}, 1-2 \mathrm{~mm}\right)$ or high-affinity site $\left(K_{\mathrm{d}}, 1 \mu \mathrm{M}\right.$; Michalak et al., 1999). To determine the $\mathrm{Ca}^{2+}$ concentration required for CRT association with $\alpha_{\mathrm{v}}$-integrin receptor and PLP, cell samples were lysed in the presence of several $\mathrm{Ca}^{2+}$ concentrations, and $\mathrm{Ca}^{2+}$ concentration was kept constant throughout the subsequent immunoprecipitation experiment (Fig. 7). A dramatic increase in CRT associated with PLP was seen when the $\mathrm{Ca}^{2+}$ concentration was raised from 0 (in the presence of $5 \mathrm{~mm}$ EGTA) to $20 \mu \mathrm{M}$, but no significant change was noted beyond that, up to $1 \mathrm{~mm}$. These data suggest that carbacholinduced mobilization of $\mathrm{Ca}^{2+}$ from intracellular stores, typically in this range of $\mathrm{Ca}^{2+}$ concentration, results in $\mathrm{Ca}^{2+}$ binding to the high-affinity site of CRT leading to increased association of CRT with $\alpha_{\mathrm{v}}$-integrin and PLP.

The PLP- $\alpha_{\mathrm{v}}$-integrin-CRT complex binds ECM proteins To determine whether CRT and PLP can modulate $\alpha_{\mathrm{v}} \beta 5$ integrin interaction with extracellular ligand in oligodendrocytes, we mea- 


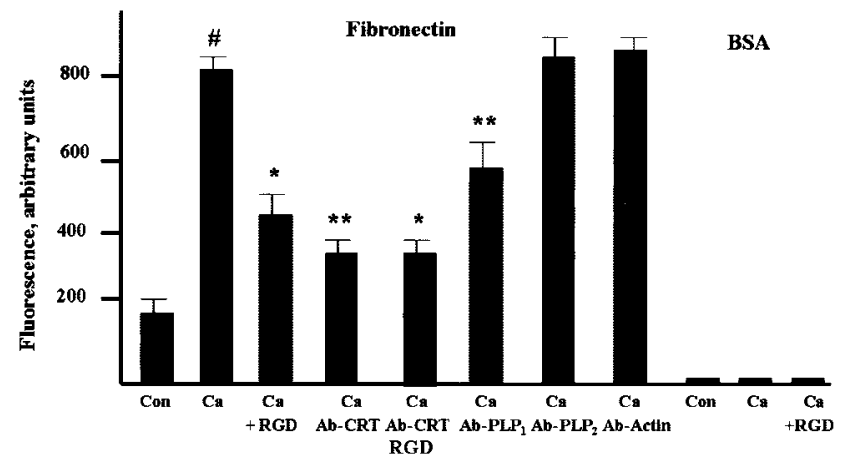

Figure 8. Fibronectin and BSA binding to integrin receptors in oligodendrocytes. Enriched oligodendrocyte cultures were preincubated for 30 min with RGDS peptide (50 $\mu \mathrm{M}, R G D)$, CRT antibody (1:100, $A b-C R T)$, PLP antibody specific for the extracellular C-D loop (1:100, $\left.A b-P L P_{1}\right)$, PLP antibody specific to C terminus (1:100, $\left.A b-P L P_{2}\right)$, a combination of CRT antibody (1:100) and RGDS peptide $(50 \mu \mathrm{M})$, or control (anti-actin) IgG (1:100, Ab-Actin). Cells were then either untreated (Con) or treated with $2 \mathrm{mM} \mathrm{Ca}^{2+}$ (all other samples) for $10 \mathrm{~min}$, and then incubated with $10 \mu \mathrm{g}$ of fibronectin-Alexa Fluor 488 conjugate (Fibronectin) or with 10 $\mu \mathrm{g}$ of BSA-Alexa Fluor 488 (BSA) for $30 \mathrm{~min}$, washed twice with PBS, and the fluorescence was measured. Data presented are means \pm SEM (3-6 replicates from at least 3 independent experiments). Nonspecific binding of fibronectin-BSA to wells filled with medium was subtracted from all measurements. Fibronectin binding significantly increased in the presence of $\mathrm{Ca}^{2+}$ ( ${ }^{\#} p<0.01$, compared with untreated control). Antibody and RGDS peptide treatment modulated fibronectin binding compared with cells treated with $\mathrm{Ca}^{2+}:{ }^{*} p<0.05,{ }^{* *} p<0.01$.

sured fibronectin binding to oligodendrocytes (Fig. 8). Fibronectin is produced by cells in the ventricular zone and is distributed along radial glial processes in early cortical development (Pearlman and Sheppard, 1996). Thus, it may play a role in early neuronal and glial migration and differentiation. Enriched oligodendrocyte cultures exhibited rather low binding of fibronectinAlexa 488 conjugate, unless the $\mathrm{Ca}^{2+}$ concentration in the incubation medium was raised. Thus, although extracellular $\mathrm{Ca}^{2+}$ was not required for the formation of the tripartite complex (Fig. $6 B)$, it significantly enhanced fibronectin binding to the complex. Fibronectin binding was suppressed by RGDS peptide, which is a potent inhibitor of $\alpha_{\mathrm{v}} \beta 5$ binding activity, indicating that the $\mathrm{Ca}^{2+}$-dependent fibronectin interaction with oligodendrocytes was mediated by the integrin receptor. In addition, fibronectin binding was suppressed by CRT antibody, suggesting that CRT might be involved in the binding or that CRT association with the integrin may modulate ligand binding. The combination of RGDS peptide and polyclonal anti-CRT antibody did not produce any further suppression of fibronectin binding. PLP antibody directed against $\mathrm{C}$ terminus, which is exposed to cytosol, did not affect fibronectin binding. However, PLP antibody specific for the extracellular C-D loop domain of PLP, which binds live oligodendrocytes (Fig. 3), inhibited binding of fibronectin to oligodendrocytes, suggesting PLP involvement in modulation of the integrin-ligand interaction (Fig. 8). Antibody against other oligodendrocyte-specific proteins, such as MOG and CNP, did not affect fibronectin binding (data not shown). There was no generic effect of rabbit IgG directed against an irrelevant antigen on ligand binding, nor was there binding of AlexaFluor 488-BSA conjugate to oligodendrocytes. Our data demonstrate that soluble ligand binding to integrin receptor on oligodendrocytes is stimulated by extracellular $\mathrm{Ca}^{2+}$ and is influenced by the CRT and PLP association with the integrin receptor.

As noted above, mAChR stimulation enhances complex for-
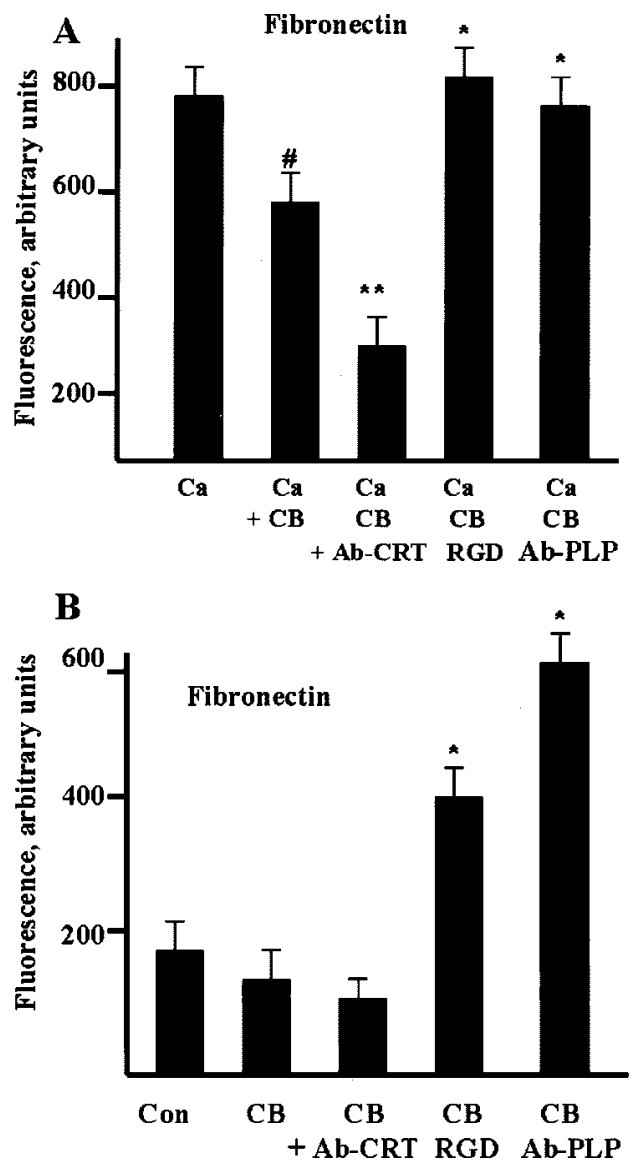

Figure 9. mAChR stimulation affects $\mathrm{Ca}^{2+}$-dependent $(A)$ and $\mathrm{Ca}^{2+}$ independent $(B)$ fibronectin binding to the integrin receptor in oligodendrocytes. Enriched oligodendrocyte cultures were preincubated for 30 min with RGDS peptide (50 $\mu \mathrm{M}, R G D)$, or CRT antibody (1:100, $A b$ $C R T)$, or PLP antibody specific for extracellular C-D loop (1:100, $A b$ $P L P$ ). Cells were then treated with $2 \mathrm{mM} \mathrm{Ca}^{2+}$ and $100 \mu \mathrm{M}$ carbachol (A, $\mathrm{Ca}+\mathrm{CB})$ or with $100 \mu \mathrm{M}$ carbachol alone $(B, \mathrm{CB})$ for $10 \mathrm{~min}$, and the incubation continued for another $30 \mathrm{~min}$ in the presence of $10 \mu \mathrm{g}$ of fibronectin-Alexa Fluor 488 conjugate. Oligodendrocytes were washed with PBS, and the fluorescence was measured. Data presented are means \pm SEM (3-6 replicates from at least 3 independent experiments). Nonspecific binding of fibronectin to wells filled with medium was subtracted from all measurements. $A$ shows the effects of carbachol on fibronectin binding in the presence of $\mathrm{Ca}^{2+}\left({ }^{\#} p<0.05\right.$, compared with untreated control; $* p<0.05,{ }^{* *} p<0.01$, compared with carbacholtreated control). In $B$, statistical significance $\left({ }^{*} p<0.05\right)$ of fibronectin binding to oligodendrocytes was compared with carbachol-treated cells.

mation and the amount of activated $\alpha_{\mathrm{v}}$ integrin in the complex. We therefore tested its effect on the ECM binding activities of oligodendrocytes, by measuring fibronectin binding to cells pretreated with $100 \mu \mathrm{M}$ carbachol for $10 \mathrm{~min}$ (Fig. 9A). Surprisingly, ligand binding was slightly reduced in cells stimulated with carbachol plus $\mathrm{Ca}^{2+}$, compared with ligand binding in the presence of $\mathrm{Ca}^{2+}$ alone; it was still sensitive to suppression by CRT antibody. However, $\mathrm{Ca}^{2+}$-dependent fibronectin binding was not inhibited by either RGDS peptide or PLP antibody, but rather stimulated in carbachol-treated oligodendrocytes. RGDS peptide and PLP antibody also stimulated $\mathrm{Ca}^{2+}$-independent fibronectin binding to oligodendrocytes treated with carbachol (Fig. 9B). Thus, mAChR stimulation of oligodendrocytes resulted in substantial changes in the integrin receptor interaction with the ligand, presumably from conformational changes in the tripartite PLP-CRT $-\alpha_{\mathrm{v}}$-integrin complex. 


\section{DISCUSSION}

Our data demonstrate that agonist stimulation of $\mathrm{mAChR}$ on oligodendrocytes enhanced formation of a complex containing $\alpha_{\mathrm{v}}$ $\beta 5$ integrin receptor, CRT and PLP by direct interaction of PLP with the cytoplasmic domain of $\alpha_{\mathrm{v}}$-integrin in oligodendrocytes. Our studies provide, for the first time, molecular evidence for participation of PLP and CRT in signaling in oligodendrocytes, and we confirm and extend earlier studies suggesting that $\alpha_{\mathrm{v}} \beta 5$ integrin is a critical modulator of oligodendrocyte maturation and myelin gene expression.

\section{Role of integrins in oligodendrocyte differentiation}

Integrin-mediated interactions influence many aspects of cell behavior, including cell morphology, migration, proliferation, and differentiation. Oligodendrocytes express a limited repertoire of integrins: $\alpha_{6} \beta 1, \alpha_{\mathrm{v}} \beta 1, \alpha_{\mathrm{v}} \beta 3, \alpha_{\mathrm{v}} \beta 5$, and $\alpha_{\mathrm{v}} \beta 8$ (Milner and ffrenchConstant, 1994), which are likely involved in important adhesive events, perhaps during oligodendrocyte migration and myelination (Milner et al., 1997; Milner, 1997). An essential role of $\beta 1$ integrins in myelination has been demonstrated in elegant studies from the ffrench-Constant group (Relvas et al., 2001). $\alpha_{6} \beta 1$ is expressed throughout development, but $\alpha_{\mathrm{v}}$ integrins exhibit developmental regulation; oligodendrocyte differentiation is accompanied by a loss of $\alpha_{\mathrm{v}} \beta 1$ and an upregulation of $\alpha_{\mathrm{v}} \beta 5$ (Blaschuk et al., 2000). $\alpha_{\mathrm{v}} \beta 1$ integrin is involved in oligodendrocyte progenitor migration (Milner et al., 1996), and it has been suggested that $\alpha_{\mathrm{v}} \beta 3$ may regulate oligodendroglial cell proliferation (Blaschuk et al., 2000). Oligodendrocytes appear to use $\alpha_{\mathrm{v}} \beta 3$ and $\alpha_{\mathrm{v}} \beta 5$ integrins for process extension (Buttery and ffrench-Constant, 2001). Interestingly, treatment of oligodendrocytes with RGD synthetic peptide, which blocks $\alpha_{\mathrm{v}}$-integrin function, results in a substantial decrease in the mRNAs encoding several myelin proteins including $\mathrm{MBP}, \mathrm{CNP}$, and PLP in oligodendrocytes (Cardwell and Rome, 1988a,b). In addition, blocking antibody against $\alpha_{\mathrm{v}} \beta 5$ integrin dramatically reduces MBP expression in CG-4 cells transfected with $\alpha_{\mathrm{v}} \beta 5$ integrin receptor, suggesting that signaling through $\alpha_{\mathrm{v}} \beta 5$ integrin is critical to continued differentiation (Blaschuk et al., 2000). PLP interaction specifically with $\alpha_{\mathrm{v}} \beta 5$ integrin, which is upregulated in oligodendrocytes with the onset of terminal differentiation and the appearance of differentiation markers such as PLP and MBP, further suggests an important role of $\alpha_{\mathrm{v}} \beta 5$ integrin in mature oligodendrocytes.

Selective PLP interaction with the integrin receptor, in the absence of DM20, supports the idea that PLP and DM20 have distinct roles in oligodendrocytes. It is noteworthy that PLP, but not DM20, is an inositol hexakisphosphate-binding protein and has been implicated in vesicular transport regulation in oligodendrocyte (Yamaguchi et al., 1996). DM20 cannot replace PLP in CNS myelin of a knock-in mouse (Stecca et al., 2000). In this knock-in mouse, wild-type levels of $P l p$ gene expression were found, but the gene was modified to express only DM20. A1though DM20 was incorporated into the functional compact myelin sheath, PLP was required to produce the normal myelin period and to confer long-term stability on the multilamellar membrane. Thus, clearly PLP, which contains a unique 35 amino acid segment on the cytoplasmic surface of the bilayer, has specific and essential interactions with proteins and lipids that DM20 does not.

\section{Integrin signaling in oligodendrocytes}

Integrin activation involves modulation of both ligand binding affinity and avidity modulation, which may reflect changes in lateral mobility and integrin clustering (Ginsberg et al., 1992; Humphries, 1996). For example, vascular endothelial growth factor (VEGF) activates $\alpha_{\mathrm{v}}$-integrin function and induces enhanced cell adhesion, migration, and soluble ligand binding (Byzova et al., 2000). In addition, selective recruitment of high-affinity $\alpha_{\mathrm{v}}$ integrins has been identified as a mechanism by which lamellipodia promote formation of new adhesions at the leading edge in cell migration (Kiosses et al., 2001). Acetylcholine and muscarinic receptor agonists modulate adhesive properties of many cells, for example, stimulating cell-substrate attachment and formation of intercellular junctions in keratinocytes (Grando, 1997). mAChR stimulation of HEK cells results in activation of integrins which, in turn, transmits a signal inside and outside the cell, leading to phosphorylation of intracellular cytoskeletal proteins and clustering of extracellular domains of integrins to form focal adhesions (Slack, 1998). Our data showing that PLC activity was required for PLP recruitment into the integrin signaling complex in oligodendrocytes are in line with previous observations that mAChRs transmit their signal via G-proteins of $\mathrm{Gq}$ family to activate PLC (Nathanson, 2000). Our results strongly suggest that acetylcholine could mediate some neuron-oligodendrocyte interactions, which could be important regulators of myelination or oligodendrocyte function in the CNS.

Since the discovery of CRT as a minor $\mathrm{Ca}^{2+}$-binding protein of the sarcoplasmic reticulum, appreciation of its importance has grown, and it is now recognized to be a multifunctional protein that is associated with cellular responses in many ways. Only a few proteins have been reported to interact with the $\alpha$-subunit of the integrin receptors, including paxillin (Liu et al., 1999), CRT (Rojiani et al., 1991), and PLP (this study). CRT binding to $\alpha$-integrin has been proven to be critical for regulating integrinmediated cell adhesion in other systems. Our study highlights the participation of CRT in integrin-ligand interaction in oligodendrocytes. Our data clearly show the presence of CRT on the surface of oligodendrocytes (Figs. 2, 3). However, data on CRT association with integrins show that it interacts with the cytoplasmic tail of the $\alpha_{\mathrm{v}}$-integrin (Rojiani et al., 1991), and chelating intracellular $\mathrm{Ca}^{2+}$ removes CRT from the PLP-integrin-CRT complex (Fig. 6B), suggesting an intracellular localization. This dichotomy is unresolved, but it has been proposed that two forms of CRT may exist, an endoCRT molecule localized on the intracellular surface of the plasma membrane and an ectoCRT molecule localized on the extracellular surface of cells ( $\mathrm{Zhu}$ et al., 1997). Thus, further characterization of the CRT associated with this complex is needed.

The functional consequences of $\mathrm{mAChR}$ activation in oligodendrocytes and of PLP association with the integrin complex are unclear. Before carbachol stimulation of oligodendrocytes, integrin binding to fibronectin is relatively consistent with known integrin activities (Fig. 8). Thus, RGD peptide reduces binding of fibronectin. In addition, a series of antibodies reduces ligand binding, although this can be used at the present time only as a measure of the presence of these proteins in the complex, not to assess their role in binding fibronectin. Quite intriguingly, after carbachol stimulation of oligodendrocytes, the conformation of the complex clearly changes, such that fibronectin binding is quite different (Fig. 9). CRT antibody binding reduces fibronectin binding, whereas PLP antibody and $\boldsymbol{\alpha} \mathrm{v}$ antibody (data not shown) actually increase fibronectin binding. These antibody studies are most likely detecting a conformational shift of the overall complex and are not a measure of the specific contribution of one protein. Most remarkably, adding RGD peptide to carbachol-treated oli- 
godendrocytes actually enhanced fibronectin binding after carbachol stimulation of oligodendrocytes. This is inconsistent with the traditional concept of RGD function as a competitive inhibitor of ligand binding to the active site of integrins. However, such results have been obtained in other studies, where incubation of platelet lysates with RGD peptide was associated with increased ligand binding properties of $\alpha_{\mathrm{IIb}} \beta_{3}$ integrin (Du et al., 1991). In that study, it was shown that the peptide that activated $\alpha_{\text {IIb }} \beta_{3}$ integrin was binding to the same site that is normally inactivated by RGD binding. Thus, it is likely that a conformational shift in this complex after mAChR activation in oligodendrocytes alters ligand binding in a unique manner. This question is under further investigation.

The fact that mAChR stimulation caused PLP, but not DM20, association with the activated $\alpha_{\mathrm{v}}$-integrin strongly implicates PLP as a novel participant in the integrin receptor adhesion complex and signaling in oligodendrocytes. The PLP interaction with integrin is rather intriguing. As noted above, the only sequence difference between PLP and DM20 is a 35 amino acid segment in the cytoplasmic domain of PLP. Thus, the fact that only PLP interacts with the integrin receptor suggests that this domain of PLP may be important for the interaction. Because we have shown direct PLP binding to the $\mathrm{C}$-terminal peptide of the cytoplasmic tail of the $\alpha_{\mathrm{v}}$-integrin, the interaction of PLP and $\alpha_{\mathrm{v}}$-integrin appears to occur between the cytoplasmic domain of PLP and the cytoplasmic tail of $\alpha_{\mathrm{v}}$-integrin. These data are consistent with earlier studies showing that intracellular events influenced the conformation and extracellular ligand binding affinity of integrins through their cytoplasmic domain (Ginsberg et al., 1992). For example, the tight association of paxillin, which is an intracellular signaling adaptor protein that interacts with the cytoplasmic tail of $\alpha_{4}$, may regulate cellular function by modifying the kinetics of integrin signaling (Liu et al., 1999). On the other hand, potential participation of the extracellular domain of PLP in the interaction remains to be investigated, because some integral membrane proteins such as PDGF-R $\beta$ and VEGF-R2 have been reported to interact with integrins via their extracellular domain (Borges et al., 2000).

\section{Potential functions of PLP gene family members}

The myelin PLP is the earliest identified member of a small family of membrane proteins, which includes $\mathrm{DM} \alpha, \mathrm{DM} \beta$, and DM $\gamma$ (Kitagawa et al., 1993). The other members of this family were initially identified as edge membrane antigen (EMA) (Baumrind et al., 1992) or M6 (Yan et al., 1993), which were characterized as neuronal proteins that were involved in neurite outgrowth. These proteins are more closely related to DM20, rather than PLP, although because PLP is identical to DM20 except for its unique 35 amino acid cytoplasmic domain, there is a high degree of homology with PLP as well. EMA is localized on the surface of the leading edge of growth cones, where it has been proposed to mediate interactions with the extracellular environment. M6, apparently the same protein, is also localized to growth cones, and antibody directed against it blocks neurite extension in cultured neurons (Lagenaur et al., 1992). Thus, it was proposed that this protein was involved in cell adhesion during neurite extension.

In early studies, PLP/DM20 was shown to induce sodiumdependent conductance in lipid bilayers (Ting-Beall et al., 1979) and act as a dicyclohexylcarbodiimide-inhibitable ion channel (Lin and Lees, 1982, 1984). Thus, it can act as a $\mathrm{Na}^{+}-\mathrm{Ca}^{2+}-$, or proton ionophore in liposomes (Helynck et al., 1983; de Cozar et al., 1987; Diaz et al., 1990), but these activities have been very difficult to study in vivo. M6 is also localized on the apical surface of proximal renal tubules and the apical surface of the choroid plexus, which are sites of significant ion transport. Evolutionary studies have demonstrated that the proteins in this family contain a 100 amino acid domain, whose closest relatives appear to be segments within the $\alpha$ subunit of the nAChR in Torpedo and the rat brain GluR (Kitagawa et al., 1993), and it was suggested that these proteins may have evolved from proteins that were closely related to ligand-gated channels. Thus, it has been suggested that these PLP/DM20-related proteins may participate in ion transport.

As noted, several of the PLP gene family members are localized to growth cones. Other crucial proteins for growth cone function are integrins, which are important contact points for growth cones and the ECM (McKerracher et al., 1996). Interaction of integrin receptors with substrate regulates calcium transients in growth cones, which in turn control substrate-dependent growth cone turning (Gomez et al., 2001). It should be noted that PLP/DM20 has been shown to enhance $\mathrm{Ca}^{2+}$ fluxes, possibly by means of a protein conformational change (Diaz et al., 1990). Thus, the possibility exists that those proteins in the PLP/DM20 gene family that are localized in growth cones may participate in complexes with integrins and potentially also CRT. Our studies demonstrate that DM20 itself, which is more closely related to the other PLP/DM20 gene family members, does not interact with $\alpha_{\mathrm{v}} \beta 5$. However, this integrin is present in mature cells, whereas DM20 is expressed to a greater extent in immature cells, which were not analyzed in this study. Thus, it will be important to assess whether it can interact with integrins present on more immature cells. As an intriguing concept, we would suggest that members of this PLP/DM20 protein family may participate in integrin signaling, in particular as regulated by $\mathrm{Ca}^{2+}$, in a number of cell types.

\section{REFERENCES}

Barres BA, Raff MC (1993) Proliferation of oligodendrocyte precursor cells depends on electrical activity in axons. Nature 361:258-260.

Barres BA, Raff MC (1999) Axonal control of oligodendrocyte development. J Cell Biol 147:1123-1128.

Baumrind NL, Parkinson D, Wayne DB, Heuser JE, Pearlman AL (1992) EMA: a developmentally regulated cell-surface glycoprotein of CNS neurons that is concentrated at the leading edge of growth cones. Dev Dyn 194:311-325.

Belachew S, Rogister B, Rigo J-M, Malgrange B, Moonen G (1999) Neurotransmitter-mediated regulation of CNS myelination : a review. Acta Neurol Belg 99:21-31.

Bergles DE, Roberts JD, Somogyi P, Jahr CE (2000) Glutamargic synapses on oligodendrocyte precursor cells in the hippocampus. Nature 405:187-191.

Blaschuk KL, Frost EE, ffrench-Constant C (2000) The regulation of proliferation and differentiation in oligodendrocyte progenitor cells by $\alpha_{\mathrm{v}}$ integrins. Development 127:1961-1969.

Borges E, Jan Y, Ruoslahti E (2000) Platelet-derived growth factor receptor $b$ and vascular endothelial growth factor receptor 2 bind to the b3 integrin through its extracellular domain. J Biol Chem 275:39867-39873.

Buttery PC, ffrench-Constant C (2001) Process extension and myelin sheet formation in maturing oligodendrocytes. Prog Brain Res 132:115-130.

Byzova TV, Goldman CK, Pampori N, Thomas KA, Bett A, Shattil SJ, Plow EF' (2000) A mechanism for modulation of cellular responses to VEGF: activation of the integrins. Mol Cell 6:851-860.

Cardwell MC, Rome LH (1988a) Evidence that RGD-dependent receptor mediates the binding of oligodendrocytes to a novel ligand in a glial-derived matrix. J Cell Biol 107:1541-1549.

Cardwell MC, Rome LH (1988b) RGD-containing peptides inhibit the synthesis of myelin-like membrane by cultured oligodendrocytes. J Cell Biol 107:1551-1559.

Cohen RI, Almazan G (1994) Rat oligodendrocytes express muscarinic receptors coupled to phosphoinositide hydrolysis and adenylyl cyclase. Eur J Neurosci 6:1213-1224. 
Coppolino M, Dedhar S (2000) Bi-directional signal transduction by integrin receptors. Int J Biochem Cell Biol 32:171-188.

de Cozar M, Lucas M, Monreal J (1987) Ionophoric properties of the proteolipid apoprotein from bovine brain myelin. Biochem Int 14:833-841.

Delwel GO, Hogervorst F, Sonnenberg A (1996) Cleavage of the $\alpha 6 \mathrm{~A}$ subunit is essential for activation of the $\alpha 6 \mathrm{~A} \beta 1$ integrin by phorbol12myristate 13-acetate. J Biol Chem 271:7293-7296.

Demerens C, Stankoff B, Logak M, Anglade P, Allinquant B (1996) Induction of myelination in the central nervous system by electrical activity. Proc Natl Acad Sci USA 93:9887-9892.

Diaz RA, Monreal J, Lucas M (1990) Calcium movements mediated by proteolipid protein and nucleotides in liposomes prepared from the endogenous lipids from brain white matter. J Neurochem 55:1304-1309.

Du X, Plow EF, Frelinger AL, O'Toole TE, Loftus JC, Ginsberg MH (1991) Ligands "activate" integrin $\alpha_{\operatorname{IIb} \beta 3}$ (Platelet GPIIb-IIIa). Cell 65:409-416.

Duchala CS, Asotra K, Macklin WB (1995) Expression of cell surface markers and myelin proteins in cultured oligodendrocytes from neonatal brain of rat and mouse: a comparative study. Dev Neurosci 17:70-80.

Eng LF, Chao FC, Gerstl B, Pratt D, Tavaststjerna MG (1968) The maturation of human white matter myelin. Fractionation of the myelin membrane proteins. Biochemistry 7:4455-4465.

Felder CC, Poulter MO, Wess J (1992) Muscarinic receptor-operated $\mathrm{Ca}^{2+}$ influx in transfected fibroblast cells is independent of inositol phosphates and release of intracellular $\mathrm{Ca}^{2+}$. Proc Natl Acad Sci USA 89:509-513.

Folch J, Lees M (1951) Proteolipids, a new type of tissue lipoproteins. Their isolation from brain. J Biol Chem 191:807-817.

Ginsberg MH, Du X, Plow EF (1992) Inside-out integrin signaling. Curr Opin Cell Biol 4:766.

Gomez TM, Robles E, Poo M, Spitzer NC (2001) Filopodial calcium transients promote substrate-dependent growth cone turning. Science 291:1983-1987.

Gow A, Gragerov A, Gard A, Colman DR, Lazzarini RA (1997) Conservation of topology, but not conformation, of the proteolipid proteins of the myelin sheath. J Neurosci 17:181-189.

Grando SA (1997) Biological functions of keratinocyte cholinergic receptors. J Invest Dermatol Symp Proc 2:41-48.

Helynck G, Luu B, Nussbaum JL, Picken D, Skalidis G, Trifilieff E, Van Dorsselaer A, Seta P, Sandeaux R, Gavach C, Heitz F, Simon D, Spach G (1983) Brain proteolipids. Isolation, purification and effect on ionic permeability of membranes. Eur J Biochem 133:689-695.

Humphries MJ (1996) Integrin activation: the link between ligand binding and signal transduction. Curr Opin Cell Biol 8:632-640.

Johnson S, Michalak M, Opas M, Eggelton P (2001) The ins and outs of calreticulin: from the ER lumen to the extracellular space. Trends Cell Biol 11:122-129.

Kidd GJ, Hauer PE, Trapp B (1990) Axons modulate myelin protein messenger RNA levels during central nervous system myelination in vivo. J Neurosci Res 26:409-418.

Kiosses WB, Shattil SJ, Pampori N, Schwartz MA (2001) Rac recruits high-affinity integrin $\alpha_{\mathrm{v}} \beta 3$ to lamellipodia in endothelial cell migration. Nat Cell Biol 3:316-320.

Kitagawa K, Sinoway MP, Yang C, Gould RM, Colman DR (1993) A proteolipid protein gene family: expression in sharks and rays and possible evolution from an ancestral gene encoding a pore-forming polypeptide. Neuron 11:433-448.

Kuryshev YA, Gudz TI Brown AM, Wible BA (2000) KChAP as a chaperone for specific $\mathrm{K}^{+}$channels. Am J Physiol Cell Physiol 278:C931-C941.

Lagenaur C, Kunemund V, Fisher G, Fushiki S, Schachner M (1992) Monoclonal M6 antibody interferes with neurite extension of cultured neurons. J Neurobiol 23:71-88.

Lees M, Brostoff SL (1984) Proteins of myelin. In: Myelin, Vol 2 (Morell $\mathrm{P}$, ed), pp 197-224. New York: Plenum.

Levine JM (1989) Neuronal influences on glial progenitor cell development. Neuron 3:103-117.

Lin L-F, Lees MB (1982) Interactions of dicyclohexylcarbodiimide with myelin proteolipid protein. Proc Natl Acad Sci USA 79:941-945.

Lin L-F, Lees MB (1984) Dicyclohexylcarbodiimide-binding sites in the myelin proteolipid. Neurochem Res 9:1515-1522.

Liu S, Thomas SM, Woodside DG, Rose DM, Kiosses WB, Pfaff M, Ginsberg MH (1999) Binding of paxillin to $\alpha_{4}$ integrins modifies integrin-dependent biological responses. Nature 402:676-680.

Macklin WB, Weill CL, Deininger PL (1986) Expression of myelin proteolipid and basic protein mRNAs in cultured cells. J Neurosci Res 16:203-217.
Maecker HT, Todd SC, Levy S (1997) The tetraspanin superfamily: molecular facilitators. FASEB J 11:428-442.

McKerracher L, Chamous M, Arregui CO (1996) Role of laminin and integrin interactions in growth cone guidance. Mol Neurobiol 12:95-116.

McCarthy KD, de Vellis J (1980) Preparation of separate astroglial and oligodendroglial cell cultures from rat cerebral tissue. J Cell Biol 85:890-902.

Michalak M, Corbett EF, Mesaeli N, Nakamura K, Opas M (1999) Calreticulin: one protein, one gene, many functions. Biochem J 344:281-292.

Milner R (1997) Understanding the molecular basis of cell migration; implications for clinical therapy in multiple sclerosis. Clin Sci 92:113-122.

Milner R, ffrench-Constant C (1994) A developmental analysis of oligodendroglial integrins in primary cells: changes in $\alpha_{\mathrm{v}}$-associated $\beta$ subunits during differentiation. Development 120:3497-3506.

Milner R, Edwards G, Streuli C, ffrench-Constant C (1996) A role in migration for the $\alpha \mathrm{v} \beta 1$ integrin expressed on oligodendrocyte precursors. J Neurosci 16:7240-7252.

Milner R, Frost E, Nishimura S, Delcommenne M, Streuli C, Pytela R, ffrench-Constant C (1997) Expression of $\alpha \mathrm{v} \beta 3$ and $\alpha \mathrm{v} \beta 8$ integrins during oligodendrocyte precursor differentiation in the presence and absence of axons. Glia 21:350-360.

Nathanson NM (2000) A multiplicity of muscarinic mechanisms: enough signaling pathways to take your breath away. Proc Natl Acad Sci USA 98:6245-6247.

Norton WT, Poduslo SE (1973) Myelination in rat brain: method of myelin isolation. J Neurochem 21:749-757.

Notterpek LM, Rome LH (1994) Functional evidence for the role of axolemma in CNS myelination. Neuron 13:473-485.

Pearlman AL, Sheppard AM (1996) Extracellular matrix in early cortical development. Prog Brain Res 108:117-134.

Popot JL, Pham Dinh D, Dautigny A (1991) Major myelin proteolipid: the 4-alpha-helix topology. J Membr Biol 120:233-246.

Relvas JB, Setzu A, Baro W, Buttery PC, LaFlamme SE, Franclin RJ, ffrench-Constant C (2001) Expression of dominant-negative and chimeric subunits reveals an essential role for $\beta 1$ integrin during myelination. Curr Biol 11:1039-1043.

Rojiani M, Finlay BB, Gray V, Dedhar S (1991) In vitro interaction of a polypeptide homologous to human Ro/SS-A antigen (Calreticulin) with a highly conserved amino acid sequence in the cytoplasmic domain of integrin $\alpha$-subunits. Biochemistry 30:9859-9866.

Ruoslahti E (1996) RGD and other recognition sequences for integrins. Annu Rev Cell Dev Biol 12:697-715.

Scherer SS, Vogelbacker HH, Kamholz J (1992) Axons modulate the expression of proteolipid protein in the CNS. J Neurosci Res 32:138-148.

Simpson P, Russel JT (1996) Mitochondria support inositol 1,4,5,triphosphate-mediated $\mathrm{Ca}^{2+}$ waves in cultured oligodendrocytes. J Biol Chem 271:33493-33501.

Slack B (1998) Tyrosine phosphorylation of paxillin and focal adhesion kinase by activation of muscarinic $m 3$ receptors is dependent on integrin engagement by the extracellular matrix. Proc Natl Acad Sci 95:7281-7286.

Stecca B, Southwood CM, Gragerov A, Kelley KA, Freidrich VL, Gow A (2000) The evolution of lipophilin genes from invertebrates to tetrapods: DM20 cannot replace proteolipid protein in CNS myelin. J Neurosci 20:4002-4010.

Tawil NJ, Wilson P, Carbonetto S (1994) Expression and distribution of functional integrins in rat CNS glia. J Neurosci Res 39:436-447.

Ting-Beall HP, Lees MB, Robertson JD (1979) Interactions of FolchLees proteolipid apoprotein with planar lipid bilayers. J Membr Biol 5:33-46.

Vinogradova O, Haas T, Plow E, Qin J (2000) A structural basis for integrin activation by the cytoplasmic tail of the $\alpha_{\mathrm{Iib}}$-subunit. Proc Natl Acad Sci USA 97:1450-1455.

Weimbs T, Stoffel W (1992) Proteolipid protein (PLP) of CNS myelin: positions of free, disulfide-bonded, and fatty acid thioester-linked cysteine residues and implications for the membrane topology of PLP. Biochemistry 31:12289-12296.

Yamaguchi Y, Ikenaka K, Niinobe M, Yamada H, Mikoshiba K (1996) Myelin proteolipid protein (PLP), but not DM20, is an inositol hexakisphosphate-binding protein. J Biol Chem 271:27838-27846.

Yan Y, Lagenaur C, Narayanan V (1993) Molecular cloning of M6: identification of a PLP/DM20 gene family. Neuron 11:423-431.

Zhu Q, Zelinka P, White T, Tanzer ML (1997) Calreticulin-integrin bidirectional signaling complex. Biochem Biophys Res Commun 232: 354-358 